[J. Appl. Glycosci., Vol. 47, No. 2, p. 201-206 (2000)]

\title{
甘藷港粉粕からペクチンの調製とその性状*
}

高峯和則**，安部淳一 ${ }^{1}$, 岩屋あまね，下野かおり，間世田春作，檜作 進 2

鹿児島県工業技術センター食品工業部（899-5105 鹿児島県姶良郡隼人町小田 1445-1）

${ }^{1}$ 鹿児島大学農学部生物資源化学科（890-0065 鹿児島市郡元 1-21-24）

2 鹿児島大学 (890-0065 鹿児島市郡元 1-21-40)

\section{Preparation of Pectin from Sweetpotato Residue and Its Characterization*}

Kazunori Takamine, ${ }^{* *}$ Jun-ichi Abe, ${ }^{1}$ Amane Iwaya, Kaori Shimono, Syunsaku Maseda and Susumu Hizukuri ${ }^{2}$

Kagoshima Prefectural Institute of Industrial Technology

(1445-1, Oda, Hayato-cho, Aira-gun, Kagoshima 899-5105, Japan)

'Department of Biochemical Science and Technology, Faculty of Agriculture, Kagoshima University (1-21-24, Korimoto, Kagoshima 890-0065, Japan)

${ }^{2}$ Kagoshima University (1-21-40, Korimoto, Kagoshima 890-0065, Japan)

The conditions for selective and effective extraction of pectin from sweetpotato residue were established. Sodium or potassium phosphate solutions of $\mathrm{pH} 7$ or above were suitable for the extraction. The gelatinization of starch in the residue, which interfered with the extraction, was minimized by extraction at $63^{\circ} \mathrm{C}$ or below. The extract was fractionated into 4 fractions, starch, arabinogalactan and pectin of two types, by DEAE-Toyopearl 650M ion-exchange chromatography. One pectin fraction had two peaks and their molecular weightes were 795,000 and 167,000, and that of the other pectin fraction was 278,000 . The uronic acid contents of the two pectin fractions were 82.4 and $92.1 \%$, respectively.

鹿児島県の基幹農作物である甘藷は，澱粉用として 年間 21 万トン生産されている。甘藷から澱粉を分離 した残留物 (以後, 澱粉粕) は, 年間約 1.5 万トン（乾 物）排出され，これまでクエン酸発酵の原料としてす べて使用されてきた。しかし，外国から安価なクエン 酸が輸入され, 製造は休止に追い込まれ, 澱粉粕の処 理が大きな問題となっている，澱粉粕の有効利用方法 として, 著者らは澱粉粕から食物瀻維の新しい製造 方法とその物理的特性について報告し, 甘藷の食物繊 維画分にはペクチンが約 $40 \%$ 含まれていることを明 らかにした。この值は, ペクチンの供給源として有用 視されている甜菜の食物瀻維画分中のペクチン含量が $30 \%{ }^{22}$ であるのと比べはるかに多い. ペクチンは食品 工業において安定化剤などとして広く利用されている が, 近年, 便通改善, 血中コレステロールレベルの上

\footnotetext{
* 甘藷澱粉粕の高度利用に関する研究（第 2 報）

${ }^{* *}$ Corresponding author.
}

昇抑制効果，高血圧抑制効果などの機能性が評価され ている3 ${ }^{3}$. ペクチンの抽出は, 繊維質材料から熱水 ${ }^{4)}$, 熱希塩酸5,6)やシュウ酸アンモニウム水溶液7,8)が用い られている。しかしながら，甘藷港粉粕中のペクチン は熱水や熱希塩酸ではほとんど抽出されない，その理 由として，甘藷から澱粉を分離する際に，磨砕した甘 藷に石灰溶液を添加し分離を容易にしているため，ペ クチンのカルボキシル基のほとんどがカルシウム塩に なっているためと考えられる．また，澱粉粕には約 $44 \%$ の澱粉が含まれている ${ }^{1)}$ た，高温下では澱粉が 糊化し, 澱粉とペクチンの分画が必要となる. 更に, シュウ酸アンモニウムは食品添加物として認められて いない.

そこで, 本研究では港粉が糊化しない条件で, か つ, 食品添加物から試薬を選定し, 澱粉粕からペクチ ンを効率よく調製する条件を検討した．また，抽出液 から透析・凍結乾燥して得られたペクチンの一般的な 性状についても検討した. 


\section{実験方法}

\section{1. 試料および試薬}

澱粉粕は, 九州化工株から供与された温風乾燥澱粉 粕を, 開口部が $840 \mu \mathrm{m}$ の笁で皮と筋の部分（乾物 比で $1.2 \%$ 含有）を除去し, 以下の実験に使用した。 ペクチンのけん化には，シグマ社製のペクチン（ガラ クツロン酸として $82 \%$ 含有，エステル化度 $89 \%$ ）を 使用した。分子量測定のための標準試料は, 昭和電工 製の Shodex STANDARDP-82（分子量が 0.59，1.18, $2.28,4.73,11.2,21.2,40.4$ および $78.8 \times 10^{4}$ のプル ラン）を用いた。

\section{2. 澱粉粕からペクチンの抽出}

1）澱粉粕懸濁液の調製

澱粉粕懸濁液は以下の方法で調製した。すなわち, 澱粉粕 $1.0 \mathrm{~g}$ （乾物当たり）に蒸留水を加え $12,000 \mathrm{rpm}$ で 30 秒間ホモジナイズ後, $1650 \times g$ で 10 分間遠心分 離した。この工程を再度行い, 得られた沈澱画分を蒸 留水で $100.0 \mathrm{~g}$ とし澱粉粕懸濁液とした.

2）抽出方法および定量方法

澱粉粕からペクチンの抽出は, 澱粉粕懸濁液をス ターラーで十分に擋找しながら $1.5 \mathrm{~mL}$ 容のプラス チックチューブに $0.95 \mathrm{~mL}$ 分注し，あらかじめ $1.0 \mathrm{M}$ に調製した Table1 に示す試薬を $50 \mu \mathrm{L}$ 添加し十分に 擋捧し，5 70 $\mathrm{C}$ でときどき擋找しながら 24 時間抽 出した。その後, 抽出液全量を $50 \mathrm{~mL}$ 容のプラス チック遠心分離管に移し，蒸留水で $40.0 \mathrm{~g}$ とし擋拌 後, $1650 \times g$ で 10 分間遠心分離した. ペクチンの構 成糖の大部分はガラクッロン酸であることが明らかに されている9)。したがって，得られた上澄み液につい て, ウロン酸は $m$-ヒドロキシジフェニル法 ${ }^{10)}$ で無水 ガラクッロン酸として定量した。また, 全糖はフェ ノールー硫酸法 ${ }^{11)}$ でグルコースとして定量した.

\section{3. イオン交換クロマトグラフィー}

抽出液のイオン交換クロマトグラフィーは Noda ら ${ }^{8)}$ の方法を一部改変して行った。すなわち，0.025 M リン酸緩衝液 (pH 5.8) で平衡化した DEAE-Toyopearl $650 \mathrm{M}$ のカラム $(3.0 \mathrm{~cm} \times 30 \mathrm{~cm})$ に抽出液を $10 \mathrm{~mL}$ 流し, $0.025,0.05,0.1,0.25$ および $0.5 \mathrm{M}$ リン酸緩衝液 $(\mathrm{pH}$ 5.8）の順でそれぞれ 52，24，24，76 および 24 分間, 次に 0.2 および $0.5 \mathrm{~N}$ 水酸化ナトリウムの順でそれぞ れ 60 分間, 最後に $0.025 \mathrm{M}$ リン酸緩衝液 $(\mathrm{pH} \quad 5.8)$ を 52 分間, 流速 $2.8 \mathrm{~mL} / \mathrm{min}$ で溶出させた. 4 分間ず つ分取し, 各フラクションについて, 全糖およびウロ ン酸量をそれぞれフェノールー硫酸法㧍よび $m$-ヒド
ロキシジフェニル法で定量した．各画分は，七ロファ ンチューブ(和光純薬社製)で蒸留水を用いて透析し, 凍結乾燥した。

\section{4. 各画分の糖組成および分子量測定}

イオン交換クロマトグラフィーで分画して得られた 凍結乾燥物 $2 \mathrm{mg}$ に蒸留水 $1 \mathrm{~mL}$ 添加し, 冷蔵庫内で 24 時間放置後十分に擋找し溶解した。なお，この操 作で溶解しない試料は沸騰浴中で溶解した。この溶液 の一部は分子量測定に供し, $100 \mu \mathrm{L}$ は $0.5 \mathrm{M}$ 硫酸溶 液 $1 \mathrm{~mL}$ に添加し， $121^{\circ} \mathrm{C}$ で 2 時間加水分解した。こ の溶液を $10 \mathrm{~mL}$ に定容後, $m$-ヒドロキシジフェニル 法でウロン酸を定量し, 残りの全量を日本ダイオネク ス社の OnGuard-A で脱硫酸後，日本ダイオネクス社 の高速液体クロマトグラフ DX500 で中性糖を定量し た. 分析条件は Shibanuma ら ${ }^{(2)}$ の方法に従った。

分子量の測定は，日本ウォーターズ社製のウルトラ ハイドロジェル 250 および $1000(7.8 \mathrm{~mm} \times 300 \mathrm{~mm})$ カラムによるゲル濾過により, 検出器は示差屈折計 （日本分光社製 RID-300），溶媒は $0.1 \mathrm{M}$ 硝酸ナトリ ウム, 流速は $0.6 \mathrm{~mL} / \mathrm{min}$, カラム温度は $40^{\circ} \mathrm{C}$ で行っ た。

5. ペクチンのけん化およびけん化したペクチンの 可溶化

1）ペクチンのけん化

ペクチンのけん化は，0.3\%に調製したペクチン溶 液 $1.0 \mathrm{~mL}$ に $1.0 \%$ 水酸化カルシウム懸濁液 $0.1 \mathrm{~mL}$ を 添加し, $5^{\circ} \mathrm{C}$ で 16 時間保存した。

2）けん化したペクチンの可溶化

けん化したペクチンの可溶化は, Table 2 に示す溶 液を添加し十分に擋找後, $60^{\circ} \mathrm{C}$ で 5 時間ときどき擋 汼して行った。 その後, $8400 \times g$ で 10 分間遠心分離 し, 得られた上澄み液の全糖をフェノール-硫酸法で 無水ガラクツロン酸を標準として定量した。

\section{実験結果および考察}

\section{1. 澱粉粕からペクチンの抽出条件}

1）澱粉粕中のウロン酸含量

著者ら ${ }^{1}$ は澱粉粕中の食物瀻維は $49.7 \%$ で，その 41.3\% がペクチンであると報告した. ペクチン中のウ ロン酸量を定量した結果 $68.5 \%$ であったことから, 澱粉粕中のウロン酸は乾物当たり $14.1 \%$ と計算され た.この值を用いて以下の実験におけるウロン酸の抽 出率を求めた.

2) 抽出試薬の影響

澱粉粕からのペクチンの抽出は, Table1に示す試 
薬を $50 \mathrm{mM}$ になるように澱粉粕懸濁液に添加し $60^{\circ} \mathrm{C}$ で 24 時間行った. その結果, 柑橘類からペクチンを 抽出する際に使用されているクエン酸, 塩酸およびリ ン酸では, ウロン酸の抽出率は $5-11 \%$ 程度であった. 缶詰や瓶詰食品のみに使用可能な EDTA や, ペクチ ンの分析に通常用いられているシュウ酸アンモニウム では, ウロン酸の抽出率はそれぞれ 94.2 および $82.8 \%$ と高い值であった. 一方, 抽出液の最終 $\mathrm{pH}$ が 中性から弱アルカリ性となるリン酸二カリウム, リン 酸三カリウムおよびリン酸二ナトリウムでは, ウロン

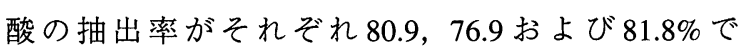
あった. しかし, 抽出液の最終 $\mathrm{pH}$ が 6 以下であるリ ン酸一カリウムとリン酸一ナトリウムでは, ウロン酸 はほとんど抽出されなかった。リン酸塩でも抽出率に 大きな差が生じることが認められた。

甘諸澱粉製造工程において甘藷を磨砕後，磨砕液に 石灰溶液を添加し澱粉と澱粉粕の分離を容易にしてい る。これは，甘藷食物纎維のペクチンがアルカリ溶液 中でカルシウムでけん化され, そのカルシウムがペク チンのカルボキシル基間を介在し, 見かけ上高分子の ペクチンとなり強固なゲルを形成する亲ことを利用し ている．そのため, 澱粉粕からぺクチンを抽出するた めには，抽出液中で 2 価以上のリン酸イオンになるよ うに $\mathrm{pH}$ を調整する必要があると考えられる。なお,

Table 1. Extraction of pectin.

\begin{tabular}{lrc}
\hline \multicolumn{1}{c}{ Reagent } & $\begin{array}{c}\text { Final } \\
\mathrm{pH}\end{array}$ & $\begin{array}{c}\text { Extraction } \\
(\%)\end{array}$ \\
\hline Potassium dihydrogenphosphate & 5.7 & 2.3 \\
Dipotassium hydrogenphosphate & 7.5 & 80.9 \\
Tripotassium phosphate & 10.0 & 76.9 \\
Sodium dihydrogenphosphate & 5.9 & 2.2 \\
Disodium hydrogenphosphate & 7.6 & 81.8 \\
Trisodium phosphate & 10.5 & 79.3 \\
Trisodium citrate & 7.6 & 81.4 \\
Sodium carbonate & 10.0 & 66.4 \\
Sodium chloride & 6.3 & 0.5 \\
Citric acid & 2.5 & 5.4 \\
Hydrochloric acid & 1.6 & 8.1 \\
Phosphoric acid & 1.9 & 10.8 \\
EDTA & 8.4 & 94.2 \\
Ammonium oxalate & 6.2 & 82.8 \\
\hline
\end{tabular}

*One $\mathrm{M}$ of each reagent $(50 \mu \mathrm{L})$ was added to a sweetpotato residue suspension $(0.95 \mathrm{~mL})$. The mixture was stood for $24 \mathrm{~h}$ at $60^{\circ} \mathrm{C}$, with occasional stirring and centrifuged at $1600 \times g$ for $10 \mathrm{~min}$.
リン酸の $\mathrm{p} K \mathrm{a}$ は $2.12 ， 7.21$ および $12.32^{13)}$ である.

そこで, エステル化度 $89 \%$ のペクチンを水酸化カ ルシウムでけん化することで, 不溶性ペクチンとし, 可溶化に及ぼすリン酸塩溶液の $\mathrm{pH}$ の影響について検 討した．その結果を Table 2 および Fig. 1 に示す.リ ン酸二ナトリウム溶液と酢酸緩衝液（pH 4.3-5.9）の 混合液を用いた場合, 不溶性ペクチンは可溶化しな かった。しかし，リン酸二ナトリウム溶液とリン酸緩 衝液（pH 6.8）との混合液㧍よびリン酸二ナトリウム 溶液のみでは，不溶性ペクチンが可溶化することが認 められた。一方, リン酸一ナトリウム溶液と水酸化ナ トリウム溶液の混合液の場合, $\mathrm{pH} 7.1$ 以上で不溶性 ペクチンが可溶化された。このことから, リン酸塩を 用いて澱粉粕からぺクチンを可溶化させるためは，抽 出液中のリン酸イオンが 2 価以上になるように $\mathrm{pH}$ を 調整することが必要であることが認められた。

3）抽出温度の影響

竹田ら ${ }^{14)}$ は, さつまいも澱粉は $65^{\circ} \mathrm{C}$ 付近から糊化 が始まり，78 $\mathrm{C}$ では完全に糊化されると報告してい る. 澱粉粕からペクチンを抽出した溶液から, ペクチ ンをエタノール沈澱法などで回収するためには，澱粉 が糊化しない条件で行う必要がある，そこで， $1 \%$ 澱 粉粕懸濁液にリン酸二ナトリウムが $50 \mathrm{mM}$ になるよ うに添加し, ペクチンの抽出を行った。 その結果,

Fig. 2 に示すように, $40^{\circ} \mathrm{C}$ 以上でウロン酸の抽出率が 急上昇し, $70^{\circ} \mathrm{C}$ で約 $82 \%$ と最も高い值であった。一 方, 全糖は, $60^{\circ} \mathrm{C}$ 付近でわずかに上昇したが, $66^{\circ} \mathrm{C}$ 以上で急激に増加した。これは澱粉粕中の澱粉が糊化 したためと考えられる。このことから，ペクチンの抽 出温度は港粉の糊化を伴わない $63^{\circ} \mathrm{C}$ を至適温度とし た。

\section{2. 抽出液のイオン交換クロマトグラフィーによる 分画}

$3 \%$ 澱粉粕懸濁液 $200 \mathrm{~mL}$ にリン酸二ナトリウムが $50 \mathrm{mM}$ になるように添加し, $63^{\circ} \mathrm{C}$ で 24 時間ときどき 擋拌しながらぺクチンの抽出を行った。 その後, $18,400 \times g$ で 20 分間遠心分離した結果, $180 \mathrm{~mL}$ の上 澄み液が得られ, ウロン酸含量が $3.91 \mathrm{mg} / \mathrm{mL}$ であっ た.この溶液の一部を $0.45 \mu \mathrm{m}$ のフィルターで濾過 した後, DEAE-Toyopearl 650M カラムで分画した。 その結果, Fig. 3に示すように, 0.025 Mリン酸緩衝液 で溶出される F1 画分 (Fraction No. 9-16)，0.25 M リ ン酸緩衝液で溶出される F2 画分 (Fraction No. 41-45), $0.2 \mathrm{~N}$ 水酸化ナトリウム溶液で溶出される F3 画分 （Fraction No. 61-69）および $0.5 \mathrm{~N}$ 水酸化ナトリウム 
Table 2. Solution for solubilization of the saponificated pectin. ${ }^{a}$

\begin{tabular}{|c|c|c|c|c|c|c|}
\hline \multirow{2}{*}{$\begin{array}{c}50 \text { mM-Disodium } \\
\text { hydrogenphosphate } \\
(\mu \mathrm{L})\end{array}$} & \multicolumn{2}{|c|}{$\begin{array}{c}1 \mathrm{M} \text {-Acetate } \\
\text { buffer }\end{array}$} & \multicolumn{2}{|c|}{$\begin{array}{c}1 \mathrm{M} \text {-Phosphate } \\
\text { buffer }\end{array}$} & \multirow{2}{*}{$\begin{array}{l}\text { Distilled water } \\
\qquad(\mu \mathrm{L})\end{array}$} & \multirow[t]{2}{*}{$\mathrm{pH}^{b}$} \\
\hline & $\mathrm{pH}$ & $(\mu \mathrm{L})$ & $\mathrm{pH}$ & $(\mu \mathrm{L})$ & & \\
\hline 180 & 3.4 & 100 & & 0 & 0 & 4.3 \\
\hline 180 & 4.0 & 100 & & 0 & 0 & 4.4 \\
\hline 180 & 4.2 & 100 & & 0 & 0 & 4.7 \\
\hline 180 & 4.9 & 100 & & 0 & 0 & 5.4 \\
\hline 180 & 5.6 & 100 & & 0 & 0 & 6.1 \\
\hline 180 & 5.9 & 100 & & 0 & 0 & 6.6 \\
\hline 180 & - & 0 & 6.8 & 100 & 0 & 7.1 \\
\hline 180 & - & 0 & - & 0 & 100 & 8.0 \\
\hline $\begin{array}{c}50 \text { mM-Sodium } \\
\text { dihydrogenphosphate } \\
(\mu \mathrm{L})\end{array}$ & & $\begin{array}{l}\text { N-Sodiu } \\
\text { droxide } \\
(\mu \mathrm{L})\end{array}$ & & $\begin{array}{l}\text { Distilled water } \\
\qquad(\mu \mathrm{L})\end{array}$ & $\mathrm{pH}^{b}$ & \\
\hline 180 & & 10 & & 90 & 6.8 & \\
\hline 180 & & 20 & & 80 & 7.0 & \\
\hline 180 & & 30 & & 70 & 7.1 & \\
\hline 180 & & 50 & & 50 & 7.3 & \\
\hline 180 & & 100 & & 0 & 8.0 & \\
\hline 180 & & 400 & & 0 & 11.1 & \\
\hline
\end{tabular}

${ }^{a}$ See text. ${ }^{b} \mathrm{pH}$ of mixture of the solution and the saponificated pectin.

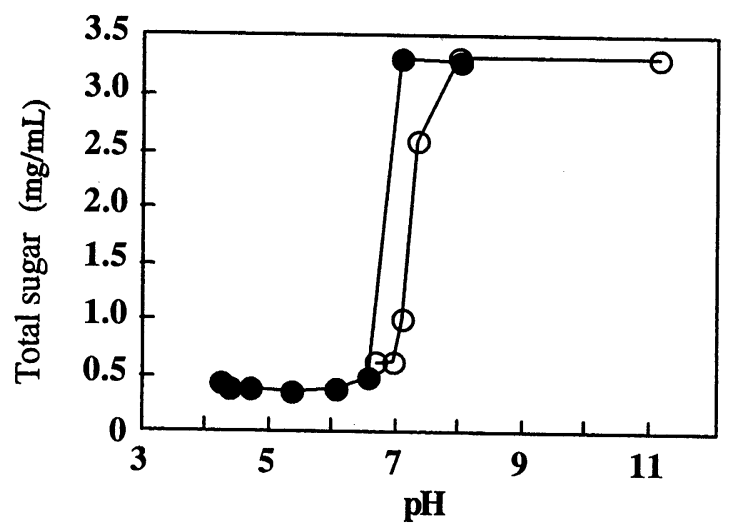

Fig. 1. Effect of $\mathrm{pH}$ of phosphate solution on the solubilization pectin gel.

$\bigcirc$, sodium dihydrogenphosphate adjusted $\mathrm{pH}$ with sodium hydroxide; $\mathbf{O}$, disodium hydrogenphosphate adjusted $\mathrm{pH}$ with acetate buffer and phosphate buffer. Conditions: see Table 2.

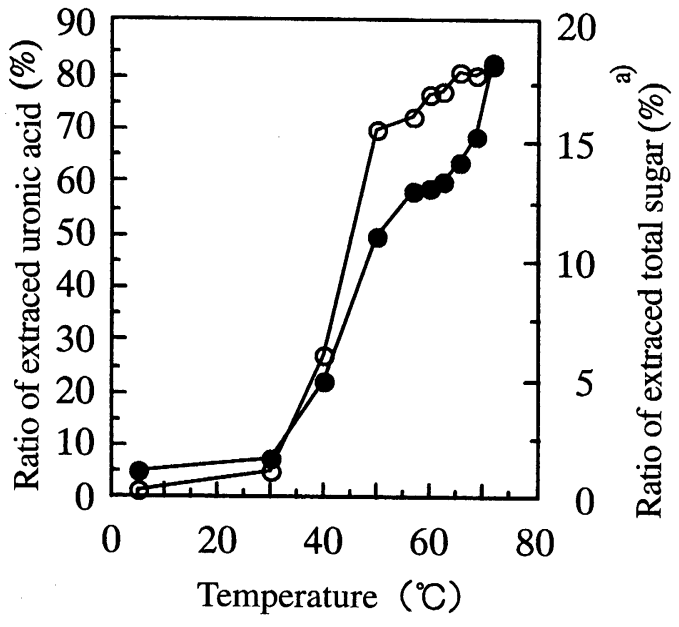

Fig. 2. Effect of extraction temperature.

a) Percentage of extracted total sugar as glucose for sweetpotato starch residue. $\theta$, uronic acid; - , total sugar. 


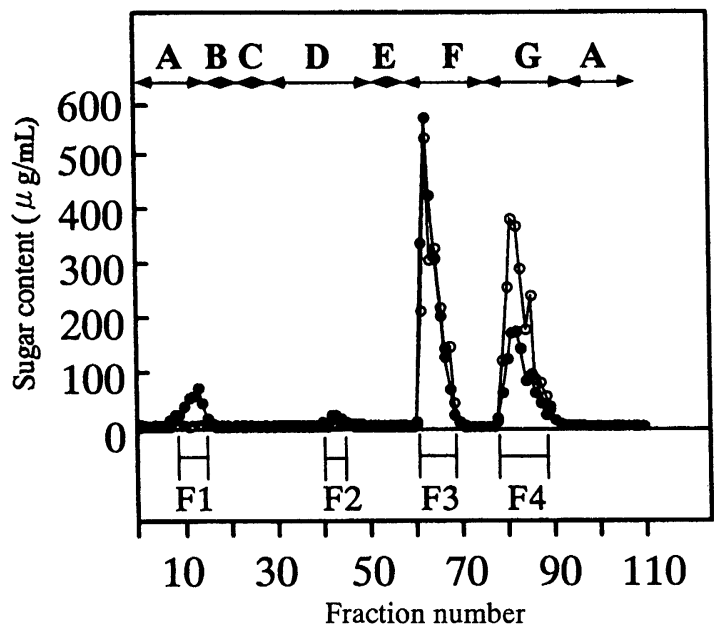

Fig. 3. DEAE-Toyopearl 650M ion-exchange chromatograms of extracted solution.

$\ominus$, uronic acid; - - , total sugar (as Glucose). A, B, C, $\mathrm{D}$ and $\mathrm{E}$ were $0.025,0.05,0.1,0.25$ and $0.5 \mathrm{M}$ phosphate buffer (pH 5.8), respectively. F and $\mathrm{G}$ were 0.2 and $0.5 \mathrm{M}$ sodium hydroxide, respectively.

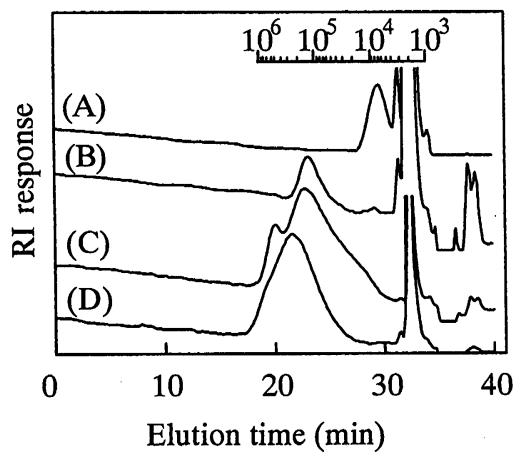

Fig. 4. Gel filtration chromatograms of Fraction 1 (A), Fraction 2 (B), Fraction 3 (C) and Fraction 4 (D).

溶液で溶出される F4 画分（Fraction No. 78-88）の四 つの画分が得られたＦ1 およびF2 画分はウロン酸が 検出されなかった。 それぞれの画分を透析, 凍結乾燥 した.

\section{3. 各画分の糖組成と分子量}

各画分の凍結乾燥物の重量比は, F1 が5.4\%, F2 が 5.6\%，F3 が $64.7 \%$ およびF4 が24.3\%であり，F3 お よびF4で 90\% 以上を占めることが認められた.

構成糖は Table 3 に示すように, F1 画分はグルコー スが 76.8\%を占めることから主に，澱粉が可溶化し た画分と考えられる．F2 画分は主にL-アラビノース
Table 3. Sugar compositions of fractions of DEAEToyopearl $650 \mathrm{M}$ column chromatography.

\begin{tabular}{ccrrrrrrc}
\hline & \multicolumn{6}{c}{ Sugar composition (\%) } \\
\cline { 2 - 7 } Fraction $^{a}$ & Rham & Ara & Gal & Glc & Xyl & Man & Uronic acid \\
\cline { 2 - 7 } & F1 & 1.9 & 5.9 & 10.7 & 76.8 & 1.3 & 3.4 & 0.1 \\
F2 & 9.1 & 29.0 & 45.8 & 7.9 & 1.4 & 6.8 & 0.0 \\
F3 & 2.9 & 5.9 & 7.9 & 0.8 & 0.1 & 0.0 & 82.4 \\
F4 & 1.3 & 2.4 & 3.0 & 0.3 & 0.2 & 0.6 & 92.1 \\
\hline
\end{tabular}

${ }^{a}$ See Fig. 3. ${ }^{b}$ As galactronis acid, anhydrous.

およびガラクトースから成っていることからアラビノ ガラクタンと考えられる. F3 および F4 画分はウロン 酸含有がそれぞれ $82.4 \% ， 92.1 \%$ であるペクチン画分 であったままた，Fig.4に示すように，F1，F2 および F4 画分の分子量はそれぞれ，6800，137,000 および 278,000 にピークがある画分であった. 一方，F3 画分 の分子量は 795,000 と 167,000 にピークがあり，その 面積比から 1 対 5 の割合であった.

\section{要約}

甘藷澱粉粕からペクチンのみを選択的に効率よく抽 出できる条件を確立した。その条件は，抽出液として $\mathrm{pH} 7$ 以上のリン酸塩が適していた. 抽出温度は $63^{\circ} \mathrm{C}$ 以下に設定することで，甘藷澱粉粕中の澱粉の可溶化 を最小限にすることができた。得られた抽出液は DEAE-Toyopearl 650M カラムにより，澱粉画分，ア ラビノガラクタン画分と二つのタイプのペクチン画分 の4 画分に分画された。 一つのペクチン画分は分子量 が，795,000 と 167,000にピークがあり，もう一つの 画分は 278,000 にピークがあり，それぞれウロン酸含 量は $82.4 \%$ および $92.1 \%$ であった。

本研究は, 科学技術庁の平成 9-11 年度科学技術振 興調整費による「地域先導研究：地域糖質資源の高機 能化と環境調和型利用システムの基盤研究」の一環と して行ったものであり，記して感謝の意を表する.

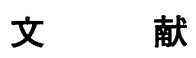

1 ) 高峯和則, 安部淳一, 岩屋あまね, 間世田春作, 檜作 進：甘藷澱粉粕から食物瀻維の新しい製造 方法とその物理的特性. 応用糖質科学, 47, 67$72(2000)$.

2 ) 青江誠一郎：食品に利用される食物纎維素材につ いて。「食物繊維」, 印南 敏, 桐山修八編集, 第 一出版, 東京, p. 341 (1995). 
3 ) 山口文秀, 内田節子, 清水典子, 前田 進, 畑中 千歳：低分子ペクチン酸を配合してなる飲食品. 特開平 05-192108 (1993).

4 ) 李 拖平, 山内 亮, 加藤宏治：サンザシペクチ ンの分画とその性状. 応用糖質科学, 45, 27-32 (1998).

5 ) 大塚洋子, 澤山 茂, 川端晶子：ルバーブの食物 繊維とくにペクチンの理化学的性質. 日本調理科 学会, 28, 146-150 (1995).

6 ) K. Kuribayashi: Properties of pressure-extracted pectin from Satsuma mandarin. in High Pressure and Biotechnology, Vol. 224, C. Balny, R. Hayashi, K. Heremans and P. Masson, eds., Colloque INSERM/ John Libbey Eurotext Ltd., Montrouge, p. 337 (1992).

7 ) 栗林 剛, 大沢克己, 高波修一, 黒河内邦夫 : 加 圧抽出した温州みかんペクチンの理化学的性質に 関する研究. 長野県食品工業試験場研究報告, 21, 26-28 (1993).

8 ) T. Noda, Y. Takahata, T. Nagata and N. Shibuya: Chemical composition of cell wall material from sweet potato starch residue. Starch/Stärke, 46, 232-
236 (1994)

9 ) 桜井直樹, 山本良一, 加藤陽治: 「植物細胞壁と 多糖類」, 培風館, 東京, p. 34 (1991).

10) N. Blumenkrantz and G. Asbsoe-hensen: New method for quantitive determination of uronic acid. Anal. Biochem., 54, 484-489 (1973).

11) M. Dubos, K.A. Gilles, J.K. Hamilton, P.A. Rebers and F. Smith: Colorimetric method for determination of sugars and related substances. Anal. Chem., 28, 350-356 (1956).

12) K. Shibanuma, K. Takamine, S. Maseda, T. Osaki, J. Abe and S. Hizukuri: Partial acid hydrolysis of corn fiber for the production of L-arabinose. J. Appl. Glycosci., 46, 249-256 (1999).

13) R. A. Day, Jr. and A. L. Underwood : 「定量分析化 学」, 鳥居泰男, 康 智三訳, 培風館, 東京, $\mathrm{p}$. 160 (1986).

14）竹田千重乃, 檜作 進 : 各種でんぷんの熱糊化の 特徵. 農化, 48, 23-29 (1974).

(2000年 1 月 5 日受付 ; 2000 年 3 月 9 日受理) 